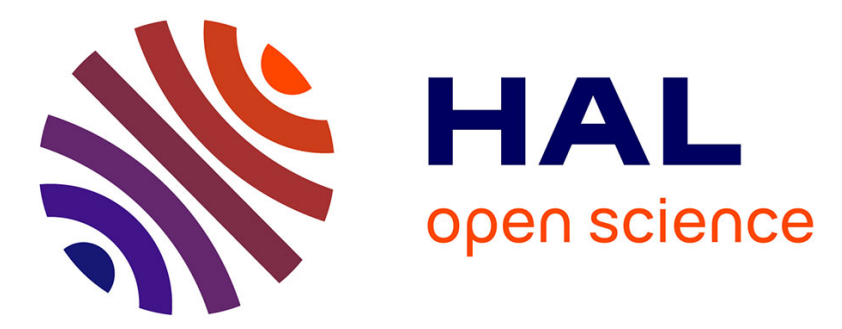

\title{
Egg mortality of Lake Geneva charr (Salvelinus alpinus L.) contaminated by PCB and DDT derivatives
}

\author{
Gilles Monod
}

\section{To cite this version:}

Gilles Monod. Egg mortality of Lake Geneva charr (Salvelinus alpinus L.) contaminated by PCB and DDT derivatives. Bulletin of Environmental Contamination and Toxicology, 1985, 35, pp.531-536. hal-01600839

\section{HAL Id: hal-01600839 \\ https://hal.science/hal-01600839}

Submitted on 2 Jun 2020

HAL is a multi-disciplinary open access archive for the deposit and dissemination of scientific research documents, whether they are published or not. The documents may come from teaching and research institutions in France or abroad, or from public or private research centers.
L'archive ouverte pluridisciplinaire HAL, est destinée au dépôt et à la diffusion de documents scientifiques de niveau recherche, publiés ou non, émanant des établissements d'enseignement et de recherche français ou étrangers, des laboratoires publics ou privés.

\section{다(1)(2)}

Distributed under a Creative Commons Attribution - ShareAlike| 4.0 International 


\title{
Egg Mortality of Lake Geneva Charr (Salvelinus alpinus L.) Contaminated by $\mathrm{PCB}$ and DDT Derivatives
}

\author{
G. Monod
}

Laboratoire d'Ecotoxicologie, I.N.R.A., Ecole Nationale Vétérinaire de Lyon, B.P. 31, 69752 Charbonnières Cédex, France

Organochlorine compounds such as PCB and $\Sigma$ DDT (pP'DDT + pp'DDE + pP'DDD) show a high chronic toxicity for various aquatic species (Mayer et al. 1977; Wassermann et al. 1979), particularly with respect to reproduction (Bengtsson 1980; Freeman and Idler 1975).

In earlier publication we noted a rather high contamination level of various fish species in Lake Geneva due to PCB (Monod and Keck 1982). Other studies have shown that Lake Geneva is widely contaminated by organochlorine residues (Burgermeister et al. 1983;

Mowrer et al. 1982). We therefore began a field study in order to determine the potential risks to reproduction by evaluating the correlation between PCB and $\Sigma$ DDT levels in the eggs of charr and their mortality rates following artificial fertilization. Indeed, many laboratory experiments stress the impact of $\mathrm{PCB}$ on fish reproduction. However, data obtained from field studies are rather wanting; among these studies, those of Johansson et a1. (1970) indicate a relationship between PCB levels and the mortality rate of coho salmon eggs.

Charr (Salvelinus alpinus $L$. ) are currently reproducing in Lake Geneva, but they are known to be highly sensitive to variations in the environment (Balon 1980; Hartmann 1983) and previous results have shown that this species is one of the most contaminated in this lake (Monod and Keck 1982).

\section{MATERIALS AND METHODS}

Wild charrs were captured on the 15th, 22nd, 16th of December 1981. The ova of 18 females were gathered individually, then fertilized with the sperm of males captured at the same moment ( 3 males per female). Each female was isolated and its age was determined by scalimetry). Eggs were maintained in a lake water sample (temperature $=6^{\circ} \mathrm{C}$ ) until their arrival at the fish farn 1 hour later, then each sample of eggs (a sample corresponds to one female) was divided into two parts.

The first part was incubated at a mean temperature level of $6.3 \pm$ $0.8^{\circ} \mathrm{C}$ with oxygen level greater than $10 \mathrm{mg} / \mathrm{L}$. The eggs were arranged in a single layer, varying in number from 385 to 817 per incu- 
Table 1. Mortality rates and levels of PCB and $\Sigma$ DDT in eggs of 18 female charr.

\begin{tabular}{|c|c|c|c|c|c|c|c|c|c|}
\hline \multirow{2}{*}{$\begin{array}{c}\text { Female } \\
\text { Age } \\
\text { (years) }\end{array}$} & \multirow{2}{*}{$\begin{array}{l}\text { Total } \\
\text { mortality } \\
(\%)\end{array}$} & \multicolumn{4}{|c|}{ Phases } & \multicolumn{2}{|c|}{$\mathrm{P} C \mathrm{~B}$} & \multicolumn{2}{|c|}{$\Sigma \mathrm{DDT}$} \\
\hline & & $\begin{array}{c}1 \\
(\%)\end{array}$ & $\begin{array}{c}2 \\
(\%)\end{array}$ & $\begin{array}{c}3 \\
(\%)\end{array}$ & $\begin{array}{c}4 \\
(\%)\end{array}$ & $\mathrm{ppm} / \mathrm{w} \cdot \mathrm{w}$. & $\mathrm{ppm} / 1$.w. & $\mathrm{ppm} / \mathrm{w} \cdot \mathrm{w}$. & $\mathrm{ppm} / \mathrm{I}$. w. \\
\hline 4 & 5.1 & 1.5 & 0.0 & 3.1 & 0.5 & 0.16 & 16 & 0.10 & 10 \\
\hline 4 & 5.7 & 0.0 & 0.0 & 4.3 & 1.4 & 0.14 & 18 & 0.071 & 8.9 \\
\hline 4 & 6.7 & 0.2 & 1.1 & 2.4 & 2.9 & 0.17 & 17 & 0.084 & 8.4 \\
\hline 4 & 8.3 & 3.2 & 0.0 & 3.2 & 1.9 & 0.12 & 13 & 0.072 & 8.0 \\
\hline 4 & 11 & 0.4 & 3.7 & 5.6 & 0.9 & 0.16 & 16 & 0.076 & 7.6 \\
\hline 4 & 13 & 4.0 & 1.5 & 4.5 & 2.6 & 0.22 & 37 & 0.14 & 24 \\
\hline 4 & 25 & 10 & 12 & 0.5 & 2.3 & 0.28 & 35 & 0.17 & 21 \\
\hline 4 & 25 & 12 & 8.5 & 2.6 & 2.1 & 0.23 & 38 & 0.11 & 19 \\
\hline 3 & 26 & 10 & 10 & 1.9 & 3.4 & 0.10 & 10 & 0.036 & 3.6 \\
\hline 4 & 28 & 5.3 & 19 & 1.3 & 1.2 & 0.13 & 16 & 0.045 & 5.0 \\
\hline 4 & 29 & 8.3 & $\uparrow 7$ & 1.0 & 2.5 & 0.28 & 35 & 0.13 & 17 \\
\hline 3 & 41 & 20 & 1.8 & 7.9 & 11 & 0.17 & 34 & 0.045 & 9.0 \\
\hline 4 & 50 & 13 & 35 & 1.0 & 1.0 & 0.14 & 16 & 0.081 & 9.0 \\
\hline 5 & 53 & 7.0 & 36 & 5.9 & 4.1 & 0.50 & 71 & 0.16 & 23 \\
\hline 4 & 59 & 8.0 & 44 & 2.4 & 5.1 & 0.19 & 27 & 0.096 & 14 \\
\hline 4 & 71 & 17 & 50 & 1.9 & 2.9 & 0.31 & 44 & 0.12 & 17 \\
\hline 3 & 72 & 21 & 46 & 1.1 & 3.6 & 0.18 & 45 & 0.096 & 24 \\
\hline 6 & 76 & 35 & 38 & 0.0 & 2.5 & 0.31 & 78 & 0.17 & 44 \\
\hline
\end{tabular}

Phase 1 : eggs without developed embryos (no visible cellular division); phase 2 : eggs with young embryos (from the first segmentations to blastula stage); phase 3 : eggs with aged embryos (from gastrula up to hatching); phase 4 : sac fry (from hatching up to yolk sac resorption).

$\mathrm{w} . \mathrm{w}$. = wet weight; $1 . \mathrm{w} .=1$ lipid weight 
bator due to differences in egg size between spawns. The dead eggs were removed daily and preserved in a simplified stockard solution (acid acetic: 5 vol., $40 \%$ formalin : 5 vol., glycerin : 5 vol. and water: 85 vol.) which made possible to observe the embryos which appeared white. After hatching the dead were also counted until the resorption of the yolk sac (about 3 months after fertilization).

For each spawn the second part was analyzed for PCB and $\Sigma$ DDT levels. The analytical method for extraction and purification has been described previously (Monod and Keck 1982). Analysis of $\Sigma D D T$ was carried out by comparison of chromatograms obtained from crude purified extract $(P C B+\Sigma D D T)$ and from the final extract ( $P C B$ + Dichlorobenzophenone) .

Correlation coefficients between concentration of organochlorine residues and mortality rates were calculated (Schwartz 1963). Percentages were expressed in arc sin $\sqrt{\text { percentage/100 }}$ for variance stabilization (Lison 1958).

\section{RESULTS AND DISCUSSION}

The total mortality (from fertilization up to yolk sac resorption) was highly variable (from 5 to $76 \%$ ) between spawns (Table 1). The age of the females would not appear to be responsible for these variations. This appears clearly in the most highly represented age group ( 4 years), in which the mortality rates vary between 5 and $71 \%$. The differences in total mortality from one spawn to another correspond mainly to variations in the levels of eggs with no visible cellular division and of eggs with young embryos.

The variability observed for the mortality levels was also found with respect to concentrations in PCB and $\Sigma$ DDT (Table 1). Among those compounds of the DDT group, PP'DDE was by far the most prevalent. This compound represents $2 / 3$ of the total concentration, while the remainder was shared by pp'DDT and PP'DDD. There is a significant and positive correlation between PCB concentrations and those of $\Sigma$ DDT.

Statistical evaluations were established using the combined data as illustrated in Table 1 . Our results show a significant and positive correlation between PCB levels in eggs and total mortality rates providing concentrations are expressed on a lipid weight basis $(P<0.01)$. No correlation exists, however, should these levels be expressed on a wetweight basis. The correlation is equally significant between the PCB level (expressed on a lipid weight basis) and the percentage of eggs without embryos (Phase 1$)(P<0.01)$, as well as the PCB level and the percentage of eggs with young nonsurviving embryos (Phase 2) $(0.01<P<0.02)$. On the other hand, no correlation appears between the contamination of the eggs and the percentage of observed mortality during the last phases of the development (phases 3 and 4 ). Similar results are obtained if one considers the contamination by $\Sigma$ DDT. 
Despite the possibility of errors resulting from the manipulation of the gametes, our results clearly indicate that the mortality level observed from the fertilization of ova to yolk sac resorption increases proportionaly with respect to increase in the contamination leve1. However, this is the case only when the concentrations are expressed on a lipid weight basis. It seems logical, from a toxicological point of view, to express PCB and $\Sigma$ DDT concentrations on the basis of simultaneously extractable lipids. The residue concentrations in the Iipid reserves and in the other structures of the eggs (particularly the embryo) probably result from a dynamic equilibrium and so, the greatest toxicological pressure exists for eggs which have the least amount of 1 ipids per unit weight. Thus, the high lipidic reserves may be considered to protect the embryo from organochlorine residues.

The toxicity of organochlorine residues should be considered from two viewpoints, the fertility of reproducers and the generation of the early stages of embryonic development.

The correlation between the level of residues and that of eggs with no visible cellular division suggests that the female fertility rate of Lake Geneva charr is influenced by organochlorine po1lutants (the percentage of embryos of a given female is used to define fertility). The influence of the relative fertilization capacity of sperm may be neglected, because the ova of each female were fertilized by the sperm of at least 3 males. To our knowledge, no studies have been carried out with respect to the influence of organochlorine residues on fertility of female fish defined as the percentage of embryos. This should not be confounded with hatchability of eggs and with the fecundity of a female which is the number of eggs per unit-weight of reproducer. PCB and $\Sigma D D T$ are potent enzyme inducers (E1combe et a1. 1979; Wassermann et al. 1979) and thus they can caise an increased hepatic catabolism of steroid hormones (Freeman et a1. 1975; Sivarajah et al. 1978). It is therefore highly possible that the female fertility rate of lake charr is decreased due to hormonal disturbances which interfere with the development of ova (Koivusaari et a1. 1984). This hypothesis becomes more substantiated if we bear in mind the close correlation between organochlorine levels in eggs and those in reproducers, providing the concentrations are expressed on a lipid weight basis(fatthews and Dedrick 1984; Monod and Keck 1982; Niimi 1983). In the present study such a correlation between organochlorine concentrations in eggs and those in corresponding female livers was observed : $P C B$ concentrations (lipid weight basis) $\mathrm{P}<0.001 ; \Sigma D D T$ concentrations (Iipid weight basis) $\mathrm{P}<0.02$.

The existing correlation between the level of residues and the percentage of dead young embryos would suggest that PCB and $\Sigma$ DDT have a toxic effect on the early stages of embryonic development. The death rates observed during the various later developmental stages are relatively low and not linked to organochlorine levels. The results observed in charr are similar in all aspects to those 
observed by Johansson et a1. (1970) in coho salmon (Oncorhynchus Kisutchl eggs: the effects of PCB levels which vary from 7.7 to 34 $\mathrm{ppm}$ (on a lipid weight basis) correlate with a mortality rate of 29 to $100 \%$ which largely corresponds to unfertilized eggs and nonsurviving young embryos. Nevertheless, some workers have noticed that yolk sac resorption is a critical phase (Burdick et al. 1964; Macek 1968; Broyles and Noveck 1979). The sensitivity of Ery during yolk sac resorption would not be at all surprising, bearing in mind that this phase is characterized by consumption of the greater part of the lipid reserves. One might suppose that the organochlorine residues stocked up to that time are then liberated, thus increasing toxicity. We do not observe such a phenomenon in our experiment.

We must remember that the correlation test employed is a statistical device which allows us to measure the intensity of the binding between two variables; and so a significant result here does not necessarily imply a cause-effect relation between these variables. It is highly probable that, in this study of charr eggs in the field, PCB and $\Sigma$ DDT are not the only pollutants present, and other types of pollution such as those by heavy metals (mercury or cadmium in the case of Lake Geneva) as well as pesticides and polychlorodibenzofurans should be taken into account. Furthermore the levels of toxicity we encountered, like those measured by Johansson are lower than those shown to be hazardous to reproduction by laboratory experiments in fish culture (Bengtsson 1980; Freeman and Idler 1975). This would indicate that the concentrations which would have an impact are clearly lower in those eggs derived from wild females than those contaminated in the more controlled environment of the laboratory. Such an observation would tend to substantiate the hypothesis of additive (and eventually synergistic) effects between different pollutants in the natural environment. Therefore it would be more prudent to consider PCB and $\Sigma$ DDT not as directly responsible for the observed mortality but as indicators of contamination by various pollutants hazardous for charr reproduction in Lake Geneva.

Acknowiedgements. I should like to express my thanks to Mssrs Bellevilie, Escome1, Jacquier, Michoux, Mudry and Renovier for their technical assistance and cooperation.

\section{REFERENCES}

Balon EK (1980) Charrs : Salmonid fishes of the genus Salvelinus. Junk $W$, The Hague, The Netherlands

Bengtsson BE (1980) Long term effects of PCB (Clophen $A_{50}$ ) on growth, reproduction and swimming performance in the minnow, Phoxinus phoxinus. Water Res 14:681-687

Broyles RH and Noveck MI (1979) Uptake and distribution of 2,4,5, $2^{\prime}, 4^{\prime}, 5^{\prime}$ hexachlorobiphenyl in fry of lake trout and chinook salmon and its effects on viability. Toxicol Appl Pharmacol 50 ; $299-308$ 
Burdick GE, Harris EJ, Dean HJ, Walker TM, Skea J, Colby D (1964) The accumulation of DDT in lake trout and the effect on reproduction. Trans Am Fish Soc $93: 127-136$

Burgermeister G, Aswald K, Machado L, Mowrer J, Tarradellas J (1983) Concentrations en PCB et DDT des sédiments superficiels de la rive suisse du lac Léman. Schweiz Z Hydrol 45 : 233-245

Elcombe CR, Franklin RB, Lech JJ (1979) Induction of microsomal hemoprotein(s) $\mathrm{P}-450$ in the rat and rainbow trout by polyhalogenated bipheny1s. Ann NY Acad Sci 320: 193-203

Freeman HC, Idler DR (1975) The effect of polychlorinated bipheny 1 on steroidogenesis and reproduction in the brook trout (Salvelinus fontinalis). Can J Biochem $53: 666-670$

Hartmann $J$ (1983) Charr as indicators of pollution. Fisheries 8 : $10-12$

Johansson N, Jensen S, O1sson M (1970) PCB indications of effects on fish. PCB conference 1 , National Swedish Environment Protection Board, p 59-67

Koivusaari U, Pesonen M, Hänninen O (1984) Polysubstrate monooxygenase activity and sex hormones in pre- and postspawning rainbow trout (Salmo gairdneri). Aquat Toxicol 5 : 67-76

Lison L (1958) Statistique appliquée à la biologie expérimentale. Gauthiers-Villars, Paris, France

Macek KJ (1968) Reproduction in brook trout (Salvelinus fontinalis) fed sublethal concentrations of DDT. J Fish Res Board Can 25 : $1787-1796$

Matthews HB and Dedrick RL (1984) Pharmacokinetics of PCBs. Ann Rev Pharmacol Toxicol $24: 85-103$

Mayer FL, Mehrle PM, Sanders HO (1977) Residue dynamics and biological effects of polychlorinated biphenyls in aquatic organisms. Arch Environ Contam Toxicol 5:501-511

Monod G and Keck G (1982) PCB in the Lake Geneva (Lake Leman) fish. Bul1 Environm Contam Toxicol $29: 570-576$

Mowrer $\mathrm{J}$, Åswald $\mathrm{K}$, Burgermeister $\mathrm{G}$, Machado L, Tarradellas J (1982) PCB in the Lake Geneva ecosystem. Ambio 11:355-358

Niimi AF (1983) Biological and toxicological effects of environmental contaminants in $\mathrm{fish}$ and their eggs. Can $\mathrm{J}$ Fish Aquat Sci $40: 306-312$

Schwartz D (1963) Méthodes statistiques à l'usage des médecins et des biologistes. Flanmarion, Paris, France

Sivarajah K, Franklin SC, Williams WP (1978) The effects of polychlorinated biphenyls on plasma steroid levels and hepatic microsomal enzymes in fish. J Fish Biol 13:401-409

Wassermann $M$, Wassermann $D$, Cucos S, Miller HJ (1979) World PCB map : storage and effects in man and his biologic environment in the 1970s. Ann NY Acad Sci 320:69-124

Received September 24, 1984; accepted November 13, 1984 